\title{
“ONDE É QUE OS BRANCOS SE ENCAIXAM?": A OBRA DE NADINE GORDIMER COMO POLÍTICA DE RECONCILIAÇÃO
}

\author{
Anderson Bastos Martins
}

\begin{abstract}
Resumo: Este artigo procura apresentar o pensamento de Nadine Gordimer acerca do papel que a população branca sul-africana poderia desempenhar quando as nações africanas, incluindo o seu próprio país, se tornassem independentes das potências coloniais europeias. Com base em duas produções ficcionais da autora e dois de seus ensaios mais conhecidos, procuro investigar a questão delineada anteriormente por meio da análise de como essa tese se desenvolveu na obra da autora num intervalo de quarenta anos de sua carreira. Estas reflexões buscam contextualizar a questão étnico-racial específica da África do Sul enquanto cenário ficcional e biográfico de Nadine Gordimer bem como expandir a questão para os debates identitários contemporâneos.
\end{abstract}

Palavras-Chave: Nadine Gordimer. Ninguém para me acompanhar. Identidades raciais. Literatura pós-apartheid.

\section{"WHERE DO WHITES FIT IN?": NADINE GORDIMER'S WRITING AS RECONCILIATION POLITICS}

\begin{abstract}
This article seeks to present Nadine Gordimer's thoughts on the role that the white South African population could potentially play when the African nations, including her own country of origin, had become independent from the European colonial powers. Based upon two of the author's fictional pieces and two of her best-known essays, I seek to look into this question by means of the analysis of how her proposition unravelled within her oeuvre in a forty-year timespan. These reflections attempt to contextualise the SouthAfrica-specific ethno-racial question as Nadine Gordimer's fictional and biographical setting as well as contribute to present-day identitarian debates.
\end{abstract}

Keywords: Nadine Gordimer. None to accompany me. Racial identities. Postapartheid literature.

\section{O mundo redescobre a África do Sul: dois momentos}

Há várias maneiras de refletir sobre as mudanças que o mundo sofre ao longo dos anos. Uma das minhas favoritas é lembrar os temas que dominam o noticiário internacional em determinado período. Houve um tempo - na verdade, há pouco tempo - em que a África do Sul dominava as 
telas das televisões nos jornais noturnos. Mas isso foi antes da Copa do Mundo de futebol de 2010, o ano em que muitos de nós descobrimos aquele país. O acompanhamento sonoro desse encontro mais recente ficou a cargo das poderosas vuvuzelas. Insuportáveis, na opinião daqueles que não compreendem que faz muito barulho e sol naquelas terras longínquas em nosso imaginário. Mas refiro-me antes ao período das décadas de 1980 e 1990. Naquele momento, a trilha sonora das notícias televisionadas desde a África do Sul não era dominada pela alegria ensurdecedora dos estádios de futebol, mas pelo estalo metálico dos rifles, pelo ronco motorizado dos blindados policiais e militares, pelas explosões aleatórias de bombas, pelos ossos quebrados por cassetetes, pelo crepitar do fogo que consumia corpos enlaçados pela borracha de pneus ensopados em querosene e em seguida incendiados.

As cenas que compunham o quadro tenebroso a que assistíamos eram originadas no drama que opunha, de um lado, os últimos representantes, em sua quase totalidade brancos, de uma política de estado em vigor desde 1948 e conhecida como sistema do apartheid e, do outro lado, líderes políticos e cidadãos comuns, em sua esmagadora maioria negros, mestiços e indianos, que exigiam a redemocratização do país e a abertura do sistema político à participação de toda a população. Acima de tudo, aquilo por que o povo sulafricano colocava o próprio corpo na linha de mira do aparato policial do estado era a luta por encerrar um regime político que havia imposto uma agressiva e violenta agenda de divisão da população por linhas étnicas e implementado um projeto de ocupação do território sul-africano ao longo dessas linhas. Na prática, o governo havia delimitado zonas para cada etnia, concedido as zonas mais nobres e ricas à minoria branca de origem europeia $\mathrm{e}$ as demais aos grupos restantes, sempre tomando o cuidado de impedir que diferentes etnias vivessem nas mesmas zonas.

A velha prática do "dividir para governar" serviu aos líderes do apartheid para normatizar todas as relações sociais por meio do critério racial e criminalizar os encontros e compartilhamentos interétnicos. Um prédio de apartamentos da cidade branca não poderia abrigar uma família negra; um aluno negro não poderia estudar em uma universidade branca; um corpo negro, se surpreendido em união com um corpo branco, era deste separado à 
força e conduzido à prisão, em obediência à chamada Lei contra a Imoralidade, cujo objetivo era impedir relações sexuais entre brancos e não brancos e que teve duas versões, a primeira promulgada em 1927, e a segunda em 1957.

\section{Nadine Gordimer e a difícil escrita da resistência}

O racismo como regra de estado fez da África do Sul um país culturalmente isolado da comunidade internacional, ainda que sua importância econômica estratégica tenha garantido o apoio ou ao menos o silêncio por parte das grandes potências internacionais durante a vigência do tenebroso sistema do apartheid.

A despeito da dificuldade de intercâmbios culturais com outros países, a esfera artística da África do Sul fervilhava durante a segunda metade do século passado. Em sua esmagadora maioria, a arte do país se contrapunha ao regime violento de vigilância e censura e procurava representar os paradoxos e as atrocidades do poder, bem como as estratégias de sobrevivência e desobediência civil dos movimentos de resistência e da classe artística.

Entre as muitas vozes que se destacaram no período, encontramos a escritora Nadine Gordimer (1923-2014), que se dedicou a denunciar o aparato estatal de controle social desde o início de sua implementação em 1948. As primeiras produções ficcionais de Nadine Gordimer datam dos anos 1930, embora seu primeiro romance, Os dias da mentira (The lying days, sem tradução no Brasil), tenha sido publicado apenas em 1953. Seguiu-se a esse uma longa carreira com a publicação de outros quatorze romances, onze livros de contos e cinco coletâneas de ensaios, além do Prêmio Nobel de Literatura de 1991. Em todas as centenas de textos da autora, a história contemporânea da África do Sul serviu de mote e de cenário para situações e personagens múltiplos que ajudaram a dar ao mundo uma percepção crítica da sociedade sul-africana do apartheid e do pós-apartheid, já que Nadine Gordimer escreveu ininterruptamente até seus últimos meses de vida.

Em 1994, foi publicado seu décimo-primeiro romance, intitulado Ninguém para me acompanhar. Sendo o primeiro livro da autora lançado no 
período pós-apartheid - 1994 foi também o ano em que teve início o governo de Nelson Mandela - Ninguém para me acompanhar acompanha - trocadilho consciente - o mundo afetivo da protagonista Vera Stark e o mundo político e cultural sul-africano, que passavam ambos por uma verdadeira revolução naquele início dos anos noventa.

Antes de refletir mais pormenorizadamente sobre algumas questões importantes nesse romance, faço uma pausa para voltar algumas décadas na rica produção ensaística de Nadine Gordimer. Em 1959, a autora publicou um texto curto mas muito significativo desde o título provocador "Onde é que os brancos se encaixam?”. A década de cinquenta na África do Sul havia dado início à derrocada do projeto de criação de uma nação multirracial e multicultural. Enquanto muitas nações africanas se tornavam estados independentes das antigas metrópoles europeias, a elite administrativa da África do Sul, por meio da instauração de um regime encabeçado por descendentes de europeus, mantinha seus laços políticos com o Velho Continente e construía um aparato estatal e policial de repressão das manifestações sociais e culturais dos negros e mestiços do país. A intelectualidade sul-africana experimentava o recrudescimento da alienação definida por linhas étnicas que marcava a história do país desde a chegada dos europeus e a subjugação das populações nativas pelas armas. O país de injustiças pontuadas por critérios raciais que encontramos em $C_{r}$, the beloved country, romance publicado por Alan Paton em 1948 que demonstrava como a estrutura de segregação racial na África do Sul se constituiu muito antes do início do regime de apartheid, já se desenhava, em 1959, como o país de atrocidades cometidas pelo estado para instalar à força um sistema político e econômico que, na prática, não passava de uma forma de escravidão disfarçada de modernidade.

$\mathrm{O}$ artigo de Nadine Gordimer de que trato aqui lançava um olhar para o futuro, um ponto incerto no tempo em que finalmente as leis do país houvessem sido mudadas de forma a conceder todos os direitos civis aos negros e mestiços em igualdades de condições com a elite branca. Naquele futuro, onde é que os brancos sul-africanos se encaixariam, qual o espaço que poderiam ou deveriam ocupar num país de população majoritariamente negra e finalmente emancipada, que função deveria ser cumprida por essa elite 
tornada por si própria indispensável para a administração dos bens públicos nacionais?

Considerando que o apartheid criou para a população negra e mestiça sul-africana um "nacionalismo do coração, gerado pelo sofrimento" (1992, p. 43), Nadine Gordimer identifica um problema central para as relações sociais futuras numa África do Sul democrática.

Ainda por muito tempo, qualquer branco sul-africano deve esperar que um negro, proveniente de qualquer outro país da África, seja considerado pelos negros sulafricanos como um irmão, muito mais irmão do que o próprio sul-africano. Nenhum elo pessoal de lealdade, amizade, ou mesmo de amor mudará tal fato (GORDIMER, 1992, p. 43).

Um tema importante analisado por Gordimer no ensaio é a permanência dos brancos numa África independente, uma vez que, à época da escrita do texto, muitos diziam que seria mais prudente retornar ou emigrar à Europa do que permanecer na África não mais como uma "minoria majoritária" mas como uma "minoria minoritária". ${ }^{1}$ Aqui estão em jogo os velhos temores dos brancos baseados em números. Sabedores de sua presença incômoda no continente, o que fazer quando os europeus e seus descendentes e representantes não mais dominassem o aparato estatal que os protegia da violência que poderia vir a ser exercida por uma massa negra e mestiça alçada ao poder? No encerramento do ensaio, que debate a pergunta do título mas sabe que não pode apresentar respostas fáceis, a autora faz uma afirmação categórica e profundamente melancólica. "Se tivermos que nos sentir primeiro brancos e só depois africanos, então seria melhor não continuar na África" (GORDIMER, 1992, p. 48).

Na parte mais otimista e propositiva do ensaio, Gordimer afirma que

se é que vamos sequer nos encaixar na nova África, terá de ser de lado, onde pudermos, onde quer que eles [os negros e mestiços] arranjem lugar para nós. Não vai ser confortável. Na verdade, vai ser mais difícil para todos

\footnotetext{
${ }^{1}$ Esse jogo de palavras foi usado por Nadine Gordimer em diversos de seus ensaios e aparições públicas no decorrer da carreira.
} 
aqueles dentre nós (e eu me incluo) que desejam fazer parte da nova África de uma forma que nos era impossível na antiga, pois nesta última a cor da nossa pele nos rotulava como opressores aos olhos dos negros, e nossas opiniões nos tornavam traidores frente aos brancos. [...] Entretanto, pertencer a uma sociedade implica em dois fatores que se situam para além da razão: o desejo de pertencer, por um lado, e a aceitação, pelo outro. [...] Se isso acontecer algum dia, será necessária a confiança de algumas gerações de independência vigilante até que a África sinta que pode permitir nossa participação na sociedade (GORDIMER, 1992, p. 42).

\section{Um salto adiante: o romance Ninguém para me acompanhar}

$\mathrm{Na}$ intenção de demonstrar como o ensaísmo de Gordimer ecoa em sua escrita ficcional, dou prosseguimento a essa análise sobre o lugar dos brancos na nova África do Sul por meio de uma breve aproximação entre esse debate e algumas situações suscitadas pelo romance Ninguém para me acompanhar, publicado em 1994.

Vera Stark, a personagem principal do livro, é uma mulher madura, provavelmente sexagenária, branca, casada em segundas núpcias com Bennet Stark, mãe de um casal de filhos, ele, Ivan, um bem-sucedido empreendedor do setor financeiro, recentemente divorciado e pai do adolescente Adam, e ela, Annie, uma médica que vive um relacionamento lésbico com Lucy, profissional das ciências biológicas. As relações que se construíram no interior desse círculo familiar serão severamente analisadas por Vera, a qual estará, no final do romance, separada de Bennet por um acordo tácito entre ambos e desobrigada, por meio de longas reflexões e embates, dos compromissos emocionais que normalmente vinculam de forma definitiva uma mãe com seus filhos. Verá terá criado novos laços, assumido novos compromissos, mas, vivendo só numa casa pequena construída no jardim da antiga casa senhorial branca hoje habitada pela elite negra do país, reconhecerá com serenidade o deslocamento, cuidadosamente elaborado pela autora do romance, que a levará de protagonista a personagem secundária tanto na narrativa quanto na estrutura social de seu país de nascimento. 
É importante sabermos que a protagonista Vera Stark se encontra, no tempo presente da narrativa, na liderança de uma equipe que presta serviços de consultoria a cidadãos que haviam sido retirados de suas terras durante o período em que os líderes do apartheid dividiram a África do Sul em regiões a serem ocupadas por etnias específicas, ou então pessoas comuns que descobriam, repentinamente, que as comunidades em que viviam estavam sendo requisitadas pelo governo para a construção de empreendimentos imobiliários ou empresariais e eram assim removidas à força de pedaços de terra onde suas famílias haviam habitado desde muitas gerações. A advogada Vera Stark tem no líder comunitário negro Zeph Rapulana um companheiro que a auxilia nas visitas aos proprietários de terra indiferentes às negociações do novo regime pela retomada de áreas usurpadas de seus ocupantes anteriores ou também na comunicação com os signatários das solicitações de reocupação de terras, em sua maioria homens e mulheres pobres, que não falavam inglês ou africânder e que baseavam suas demandas em argumentos culturais que não eram facilmente traduzíveis ao raciocínio jurídico de Vera Stark. É nesse contexto que Zeph e Vera se tornam irmãos no combate por justiça e reparação na nova África do Sul.

No decorrer da narrativa, Vera, como já mencionado, se encontra só e inteiramente dedicada a uma viagem interior, mas também a um papel de conselheira no âmbito do grupo de trabalho que se ocupa em redigir a nova constituição da nação arco-íris. Como figurado por Nadine Gordimer quase quarenta anos antes, os brancos conscientes de seu privilégio se ocupam em partilhar a expertise proporcionada a eles com os novos líderes envolvidos na gigantesca tarefa de montar as bases de uma sociedade justa e independente que, ao mesmo tempo, não aliene a minoria branca mais qualificada e nem descredencie a maioria negra condenada por uma formação profissional e técnica obtida em escolas e universidades de menor investimento estatal. Além disso, Zeph se encontra, ao final do romance, entre os integrantes de uma nova elite empresarial negra que pôde se constituir graças à intervenção do estado que garantiu a presença de representantes de todos os estratos sociais nas mais variadas esferas deliberativas do governo, da sociedade civil e das entidades empresariais. Vera vive, como já informei, numa casa anexa ao jardim da nova casa de Zeph, o líder negro que ocupa hoje a casa dos brancos. 
E é com Vera que o romance se encerra, com Vera sozinha, à noite, caminhando calma pelo jardim, os pés firmes no solo africano, desejosa de pertencer e esperançosa de ser aceita no novo país que não lhe pertence mais, mas que, justamente por essa razão, pode vir a ser a sua terra.

Assim como a grande maioria dos artistas e escritores nascidos na África em famílias europeias, Nadine Gordimer jamais ignorou as fontes de sua formação intelectual. Sempre que chamada a elencar suas influências, os nomes de Proust, Chekhov e Dostoiévski são os primeiros a serem mencionados. No entanto, desde as páginas iniciais de seu primeiro romance, Nadine Gordimer dá destaque ao abismo que se abriu entre sua experiência de leitura dos grandes autores ocidentais e suas experiências do universo africano em que nascera. Estas reflexões de Gordimer dizem respeito, em grande medida, à origem de seu afeto pela África.

Comparando-se ao pequeno Jacques de $O$ primeiro homem, romance autobiográfico de Albert Camus, Gordimer escreve que, em sua infância, caso fosse indagada sobre onde ficava sua pátria, provavelmente responderia que sua pátria era a Inglaterra. Na busca por traçar o caminho que a levou a compreender que a pátria não era um país ao qual se chegava, à época, após quatro longas semanas passadas no Atlântico, a autora toma por empréstimo uma bela imagem criada por Italo Calvino que ele usou para se referir aos filmes norte-americanos de sua juventude como "aquele outro mundo que era o mundo" (GORDIMER, 1996b, p. 117). Em sua caracterização daquele mundo, Gordimer o traz de volta à memória nos termos seguintes:

Ele atraía. Talvez, um dia, se você tivesse muita sorte, fosse muito bom, trabalhasse duro, você poderia conseguir vê-lo; e enquanto eu cresci aquele mundo tomou forma, a Londres de Dickens e Virginia Woolf, a Paris de Balzac e Proust. Já em relação à América, eu fui de Huck Finn a Faulkner e Eudora Welty; mas a América não estava no itinerário dos chefes de mineração aposentados e gerentes de turno com suas esposas, amigas de minha mãe, que passavam a vida economizando para realizarem uma só viagem para a Inglaterra, para casa, ao se aposentarem.

Aquele outro mundo que era o mundo" (GORDIMER, 1996b, p. 117-8, itálicos no original, tradução do autor). 
Na posição de criança nascida na década de 1920, em uma família branca, às margens das grandes empresas mineradoras da África do Sul, Nadine Gordimer pertenceu a um mundo social restrito ao espaço pequenoburguês da classe média de seu país. A esse grupo não tinha acesso qualquer cidadão negro ou mestiço. Por essa razão, seu amor precoce pela leitura e pela escrita levou-a a descobrir uma profunda cisão entre seu território pessoal e as experiências por ele suscitadas e o espaço literário em que ela passava a maior parte de seu tempo livre.

Esse conflito torna-se ainda mais contundente quando se leva em conta que a literatura sul-africana da época era escrita quase que exclusivamente por autores provenientes de meios sociais e origens históricas muito parecidos com a sua própria. Portanto, apesar do nascimento em solo africano, Nadine Gordimer muito cedo descobre a impossibilidade de apontar o Continente Negro como sua terra, ou o povo africano como sua gente.

Dando prosseguimento a sua analogia com o protagonista do romance de Camus, Gordimer conclui que deveria "fazer-se a si mesma, na metáfora do Primeiro Homem, sem referências coerentes, de pé sobre as próprias pernas, nenhum modelo por meio do qual prosseguir" (GORDIMER, 1996b, p. 121, itálicos no original, tradução do autor). Essa necessidade de "fazer-se a si mesma" espelha sua carência de conexões mais profundas, seja com a tradição autóctone do continente africano, seja com a cultura europeia, na qual sua participação era apenas vicária por meio de suas leituras e das origens de seus pais. ${ }^{2}$ Como escritora, Gordimer ainda deveria cumprir muitas das exigências impostas aos artistas que aspiram à legitimação no primeiro mundo da literatura mundial. Em seu entender, somente a escrita lhe daria condições de estabelecer seu papel e seu espaço na sociedade sulafricana.

Em meu desejo de escrever, na escrita que eu já estava fazendo a partir de meu conhecimento pateticamente limitado do povo e do país em que eu vivia, encontrava-se o meio de descobrir o que era a minha verdade, o que

2 Nadine Gordimer pertencia a uma família de extração judaica de recente formação na África do Sul, sendo sua mãe inglesa e seu pai letão. 
havia para eu me conectar, como eu poderia conseguir me tornar meu próprio Primeiro Homem, mulher-homem, ser humano (GORDIMER, 1996b, p. 123, tradução do autor).

Além da criação literária, um segundo fator que veio a permitir-lhe pensar na África do Sul como seu país foi o desligamento deste, ocasionado por pressões políticas, da Comunidade Britânica. Com isso, a ideia de uma pátria europeia iria aos poucos se dissolver. No entanto, Nadine Gordimer ainda estava longe de sentir-se capaz de dar o salto decisivo após o qual poderia considerar-se membro do povo sul-africano. Embora sua obra já fosse reconhecida como parte da riqueza cultural daquele país, sua cidadania não era vivida plenamente, uma vez que muitos a viam como pertencente à elite branca, privilegiada e opressora.

Até que cada lei que me situava à parte dos negros fosse abolida, até que nós todos pudéssemos nascer e seguir nossas vidas em qualquer lugar com o mesmo direito, governados pela livre escolha de todo o povo, meu lugar não teria como me conhecer. Pouco importa como eu e tantos outros nos conduzíamos, nós éramos mantidos dentro das categorias do passado. As leis que faziam com que mais dinheiro fosse gasto com a educação de uma criança branca do que a de uma criança negra, que um trabalhador branco recebesse mais do que um trabalhador negro, que os negros fossem transportados como gado a fim de existirem onde os brancos assim o decidissem - tudo isso teria que passar. Os exilados precisavam voltar para seu lar de direito; os prisioneiros de consciência tinham que ser recebidos no continente, libertados de Robben Island, ${ }^{3}$ sair da Penitenciária de Pollsmoor; ${ }^{4}$ todos aqueles que haviam sido atormentados e segregados precisavam ascender ao poder onde seus perseguidores haviam governado por tanto tempo.

Tudo isto passou.

\footnotetext{
${ }^{3}$ Ilha situada na costa da Cidade do Cabo e onde se encontrava a prisão que recebia os prisioneiros políticos do regime segregacionista do apartheid. Nelson Mandela foi o preso mais célebre a ser encarcerado ali.

${ }^{4}$ Prisão importante também situada na Cidade do Cabo onde Mandela cumpriu parte dos 27 anos em que passou detido pelo regime do apartheid.
} 
[...] Em abril de 1994 todos os sul-africanos de todas as cores foram às urnas e elegeram seu próprio governo, pela primeira vez. [...] O que isto significa para os nossos milhões é algo que não tem preço e que vai além dos acertos de contas [...]. Nós sabemos que devemos realizar o que Flaubert chamou de "a mais complexa e menos charmosa de todas as tarefas: a transição". Esta é a realidade da liberdade. É a grande questão. Eu sou uma pequena questão; mas para mim existe algo imediato, extraordinário, de forte significado pessoal. Aquele outro mundo que era o mundo não é mais o mundo. Meu país é o mundo, inteiro, uma síntese, eu não sou mais uma colona. Agora eu posso falar do "meu povo" (GORDIMER, 1996b, p. 133-4, tradução do autor).

Cito essa longa passagem praticamente na íntegra por diversas razões. Em primeiro lugar, os quatro parágrafos transcritos fornecem uma visão sucinta das condições específicas de Nadine Gordimer enquanto cidadã sul-africana durante a longa vigência das leis do apartheid. Em segundo lugar, ao depositar tamanha ênfase sobre o papel da lei nas relações humanas representadas em sua ficção, Gordimer corrobora minha hipótese acerca da relevância de criar uma personagem envolvida com a legislação, em lugar da literatura, para pintar seu autorretrato literário. ${ }^{5}$ Além disso, o final da passagem acima, ao mencionar as eleições presidenciais, os exilados e o período de transição, estabelece importantes conexões entre os temas de Ninguém para me acompanhar e algumas das preocupações que interessavam a autora durante o período de composição da obra. Como o encaminhamento das situações específicas pertinentes a tais temas parece fundamental para que Gordimer possa efetivamente pertencer ao povo sul-africano e não apenas ao solo daquele país, reforça-se a ideia de que a situação de Vera Stark ao final do romance reflete as expectativas de sua criadora em relação ao futuro da nação sul-africana. De certa maneira, é possível perceber uma analogia entre a tentativa frustrada de Vera em reconhecer a realidade sulafricana em suas referências artísticas europeias e a afirmação quase

\footnotetext{
${ }^{5}$ Em minha tese de doutorado, recorri ao conceito de "autorretrato literário", de Michel Beaujour (1980), para analisar a relação autobiográfica entre a Nadine Gordimer, a autora, e Vera Stark, a personagem.
} 
nacionalista de Gordimer ao referir-se à nova África do Sul como o "mundo" que ela havia buscado encontrar durante tantas décadas.

Nesse ponto, parece interessante analisar a situação de Vera após os principais acontecimentos que lhe dizem respeito no romance. Em um breve apanhado, à medida que Ninguém para me acompanhar se aproxima de sua conclusão, a personagem vai se despindo de suas principais referências interpessoais. Ben se encontra em Londres, vivendo com o filho do casal, e o leitor é levado a concluir que houve uma espécie de divórcio psíquico entre os Stark, uma paralisia causada pela incapacidade de Ben de amar outra mulher e a crescente irritação de Vera diante de tal sentimento de quase dependência afetiva. Além disto, Vera vai morar, como já mencionado, numa pequena casa situada no jardim da residência de Zeph Rapulana, o antigo líder comunitário elevado agora à condição de conselheiro de diversos grupos de empresários e burocratas envolvidos com o processo de transição democrática. A antiga casa de Vera, herança deixada pelos pais de seu primeiro esposo, está à venda ao fim do romance. E, por fim, a antiga advogada de uma associação voltada para a defesa da massa de sem-terras criada pelo apartheid, aceita o convite para participar do Comitê Técnico encarregado de preparar o terreno para a convocação de uma Assembleia Constituinte para a nova fase da história da África do Sul. A um só tempo, Vera descobre-se só, sem alguém que a acompanhe, na busca por uma verdade de cunho pessoal. Entretanto, Vera não está realmente só, uma vez que seu novo trabalho absorve-a de maneira incondicional e a conduz a um envolvimento nunca antes experimentado por ela com o destino de seu povo. E para completar o quadro, ao deixar a casa do período colonial em que passou a maior parte de sua vida e passar a ocupar um espaço anexo à residência de um cidadão negro emancipado econômica e politicamente pelas novas circunstâncias, Vera assume o papel idealizado por Nadine Gordimer em seu ensaio acerca da contribuição possível aos brancos quando a descolonização se concretizasse na África. Dessa forma, Vera não apenas oferece a Nadine Gordimer a chance de ilustrar seu pensamento sobre seu próprio trabalho enquanto intelectual sul-africana branca, mas também a oportunidade de produzir uma obra que constitui sua primeira contribuição literária para aqueles novos tempos. Enquanto máscara autobiográfica para a conceituação da verdade e sua relação com a lei, Vera representa o ideal de 
uma união entre leis mais justas, desatreladas de uma retórica falaciosa, e as verdades supostamente universais dos direitos humanos. Realmente Gordimer não se aproxima de uma síntese sobre a verdade, mas mantém-se firme na convicção de que certos valores não podem ser relativizados.

Na última cena de Ninguém para me acompanhar, Vera está tentando consertar um pequeno defeito no encanamento de sua nova casa e entra na cozinha de Zeph para procurar uma ferramenta. Não acende as luzes para não perturbá-lo e isso faz com que acabe se chocando com uma jovem que acabara de sair do quarto de Zeph e também se dirigira à cozinha. Sem pronunciar qualquer palavra, compreendendo que agora era o seu o corpo estranho naquele cenário, ela se retira dali.

Lá fora, na noite negro-azulada de inverno, foi como se desse um mergulho delicioso, chocante, no ar gélido. Fechou o registro com a satisfação de uma mulher executando um trabalho braçal. Em vez de voltar logo ao anexo, foi até o jardim, a jaqueta bem fechada sobre a quentura viva. O frio crestava os lábios e as pálpebras; gelava as duas cadeiras e a mesa; tudo pelado (stripped). Nem uma folha nos membros acetinados das árvores, os arbustos feito arames emaranhados; as frondes das palmeiras rígidas como os dedos. Uma trilha espessa de gelo partido crepitando luzes, as estrelas cegando quando deixou a cabeça tombar bem para trás; sob a oscilação do céu, os pés plantados no chão, no eixo do mundo noturno. Vera passeou um pouco por ali. E depois tomou seu rumo, o vapor do bafo espiralado, uma assinatura a sua frente (GORDIMER, 1996, p. 292-293).

Comentando essa passagem, a crítica Dominic Head (1995, p. 53) afirma que é possível subestimá-la. Creio ser esta uma afirmação correta. A maior parte das análises universitárias e resenhas jornalísticas do romance concentraram-se sobre o teor melancólico de sua conclusão, especialmente em se tratando de uma obra que, paralelamente às grandes questões políticas vividas pela África do Sul no período em que foi escrita, teve igualmente por tema o processo de envelhecimento de sua protagonista, a perda de interesse pelos ganhos advindos da sexualidade bem como sua opção pela solidão. 
Sem dúvida, esses são elementos presentes na passagem que encerra o romance, mas destacá-los como os mais proeminentes reduz a leitura e implica não perceber o alto grau de contentamento experimentado por Vera naquele momento. Enquanto a descrição do clima e do cenário reescreve a epígrafe de Bashō $^{6}$ selecionada por Gordimer, o corpo de Vera encontra-se aquecido, protegido do frio invernal, ou do frio interior que sinaliza a aproximação da morte. A solidão de Vera representa sua libertação - numa espécie de analogia com a emancipação de seu país e seu próprio abandono do passado colonial encenado pela venda da casa - e apenas reformula uma de suas reflexões anteriores, quando, percebendo o caráter ao mesmo tempo espontâneo e inelutável de seu distanciamento em relação a Ben, ela conclui que "todo mundo acaba rumando sozinho em direção ao eu" (GORDIMER, 1996, p. 277).

Dominic Head destaca em sua análise a distância percorrida, tanto por Gordimer quanto por toda a nação sul-africana, entre o pedido de Helen Shaw, negado por sua mãe, para que sua amiga negra Mary Seswayo ocupasse a casa dos empregados durante o semestre letivo, o que facilitaria seu acesso ao transporte até a universidade, ${ }^{7}$ e o momento em que um romance de Nadine Gordimer termina com sua protagonista, uma cidadã pertencente às classes médias privilegiadas durante o regime do apartheid, ocupando a casa dos fundos da residência de um cidadão negro emancipado política e financeiramente durante o processo de redemocratização. Trata-se da culminância do processo que venho tentando demonstrar aqui, ou seja, o momento em que Gordimer pôde efetivar ficcionalmente a tese defendida por ela acerca do espaço ocupado e da função desempenhada pelos brancos na nova África do Sul.

\footnotetext{
${ }^{6}$ Opto por citar a tradução ao inglês utilizada por Nadine Gordimer e em seguida traduzir livremente. "None to accompany me on this path/Nightfall in Autumn." (Ninguém para me acompanhar nesse percurso/Anoitecer no Outono).

7 Helen Shaw é a protagonista do primeiro romance de Gordimer, Os dias da mentira, que tem a eleição presidencial de 1948 como pano-de-fundo, ou seja, o ano em que o Partido Nacional fez maioria para formar um governo de maioria africâner e deu início à construção do edifício do apartheid. Mary Seswayo, no romance, é uma colega de classe de Helen na universidade, e a situação brevemente descrita acima é apenas a primeira de muitas reiterações na obra de Nadine Gordimer de uma relação entre personagens configurada por meio da ocupação de uma casa principal e de um anexo da casa situado no jardim ou terreno da mesma.
} 
Na busca por uma leitura autoideográfica da personagem Vera Stark em relação a sua criadora, gostaria de destacar um segundo ponto de encontro entre Os dias da mentira e Ninguém para me acompanhar.

$\mathrm{Na}$ cena final do primeiro romance, Helen Shaw põe-se à janela de um hotel na véspera de partir para a Europa e, ouvindo canções entoadas canhestramente por um grupo de rapazes negros que passavam pela rua, afirma para si mesma que sua viagem para o Velho Continente seria temporária e que ela deveria estar de volta à África do Sul em breve. Nesse momento, a personagem se encontra na sacada do quarto que ocupa, com as solas dos pés voltadas na direção do solo de seu país, embora mantidas à distância deste pela altura do prédio em que se encontra o hotel. A mesma Helen havia, momentos antes, queixado a um amigo que sua condição não lhe deixava pertencer mais que à "crosta” da África do Sul, a uma tênue superfície, o que fazia dela a verdadeira personificação do "judeu errante”. ${ }^{8}$

Quarenta anos se passaram até que encontramos Vera Stark - cujo nome representa a antítese do título do primeiro romance de Gordimer e remete à crueza da realidade de um país cuja política se baseou em falácias ideológicas que a autora buscou manter como chaga aberta em sua obra - de pé no jardim de sua nova casa, apenas desta vez seus pés tocam diretamente o solo de sua terra e não temem este contato. Na realidade, é Vera que pertence à crosta de seu país, se agora entendermos esse termo numa acepção que destaca o contato direto com o solo, o pertencimento, a autoidentificação do cidadão branco como membro de uma nação e também de um povo. A viagem de volta de Helen se completa justamente no momento em que Vera toma posse simultaneamente de seu eu mais pessoal e de sua persona pública mais destacada até então. O fim das referências meramente subjetivas - marido e filhos, a sexualidade, a casa herdada - abre espaço para o encontro deste eu desidentificado com o passado e envolvido em ações que o conduzirão ao futuro sonhado pelos pais e mães da resistência ao apartheid. Em termos coletivos, Vera espelha o desejo que os intelectuais sul-africanos nutriram

\footnotetext{
${ }^{8}$ A família de Nadine Gordimer tinha origem judaica e a autora sempre elaborou em seus ensaios o impacto que esse fato teve sobre sua visão de mundo e consequentemente sobre sua obra.
} 
para seu país a partir dos primeiros momentos de euforia com o início do desmantelamento do antigo regime.

Finalmente, no tocante à relação biográfica entre Nadine Gordimer e Vera Stark, é extremamente tentador afirmar que, ao escolher comparar a respiração de Vera, tornada visível pelo ar frio como uma emanação, com uma “assinatura", exatamente no momento em que encerra sua narrativa, ou seja, no ponto em que o artista assina sua obra, Gordimer insinua que a viagem de Helen, concretizada pela viagem interior de Vera, é análoga ao seu processo pessoal de chegada a um ponto em que poderia considerar a África do Sul como seu país e todos os sul-africanos como seu povo, bem como vivenciar, ela própria - a autora - sua proposta sobre o lugar dos brancos na África do Sul democrática que se formava.

Assim como Sibongile e Didymus Maqoma, ${ }^{9}$ Vera também viveu uma vida no exílio, ainda que por razões diferentes. O exílio de Vera em nada se diferencia da alienação a que Gordimer foi submetida durante a vigência do apartheid. Com o retorno dos Maqoma - bem como dos Mbeki, dos Slovo, dos Breytenbach - também os Stark - assim como os Gordimer, os Coetzee, os Brink - puderam reassumir papéis tornados impossíveis pelo absurdo exílio imposto àqueles que se recusaram a partir. ${ }^{10}$

\section{De volta à questão: onde é que os brancos se encaixam?}

Essa foi a tese defendida por Nadine Gordimer nos quase setenta anos de sua carreira prolífica, ou seja, a tese de que as marcas do apartheid só deixarão de se fazer sentir muito lentamente num longo processo de reconciliação que acomodará finalmente os corpos, as narrativas, as memórias e as políticas sujeitadas, cada um à sua maneira, pela desumana institucionalização do racismo enquanto política de estado.

\footnotetext{
${ }^{9}$ Casal de personagens negros de Ninguém para me acompanhar, extremamente próximos de Vera e cuja situação, retornados à África do Sul após revogadas as leis de exílio, faz com que suas vidas tomarem rumos inesperados por meio de reversões de papéis com base nas relações de gênero.

10 Referências respectivamente a Thabo Mbeki, ex-presidente da África do Sul, aos ativistas Ruth First e Joe Slovo, pais da escritora sul-africana Gillian Slovo, a Breyten Breytenbach, escritor sul-africano africâner, a J. M. Coetzee, escritor sul-africano agraciado com o Nobel de Literatura de 2003 e a André Brink, escritor sul-africano anglo-africâner.
} 
E como conclusão, dedico meus últimos parágrafos a perguntar: Será mesmo? E a refletir sobre o modesto sucesso dessa tese, passados vinte e seis anos desde o fim do regime do apartheid. E a tocar no espinhoso tema do apartheid nosso de cada dia.

O texto de Nadine Gordimer que dá título a este artigo foi publicado há mais de sessenta anos. É justo por essa razão que eu iniciei destacando algumas das cenas mais brutais do sistema do apartheid contra a população negra e mestiça da África do Sul. Estou convicto de que, àquela altura, Gordimer já se havia dado conta de que a reconciliação para a qual ela apontava estava ficando cada dia mais distante. Mas, ainda assim, a autora manteve até seus últimos dias e seus últimos livros a expectativa de que algum tipo de acordo seria possível entre o passado e o presente de seu país. E, acima de tudo, ela manteve a aposta de que as periferias podem se tornar casos de sucesso sem a eterna dependência dos países mais avançados. Ainda assim, a alta dose de utopia de seu ensaio não se mostra hoje muito plausível para a África do Sul passadas quase três décadas desde a eleição de Nelson Mandela.

O uso do verbo "encaixar" - "Onde é que os brancos se encaixam?" é uma necessidade imposta pela tradução ao português, embora contribua com uma metáfora bastante interessante para este encerramento. Antes, porém, é preciso reconhecer que tratar do espaço ocupado pelos brancos por meio de uma pergunta só faz sentido no contexto exato em que o texto de Gordimer foi pensado, já que, em outras situações, a questão se responde pela óbvia proximidade entre a pele branca e as instâncias de poder.

O multirracialismo e o multiculturalismo são frequentemente pensados por meio da possibilidade de contiguidade entre diferenças, como se muitos objetos funcional e ontologicamente diferentes fossem depositados numa única caixa. O problema começa quando percebemos que muitos desses objetos prefeririam estar numa caixa com maiores semelhanças do que diferenças. Além disso, os arquivistas responsáveis pelo depósito desse acervo múltiplo frequentemente debatem a possibilidade de organizar os objetos em números maiores de caixas onde se colocariam objetos menos dessemelhantes. Por fim, cada um de nós, os objetos concretos desse exercício de imaginação, somos informados, desde o nascimento, das caixas que nos 
comportam mais confortavelmente e daquelas que não nos "cabem" - e aqui fico mais próximo do termo original (fit in) empregado por Nadine Gordimer. Se pensarmos então as diversas sociedades como esses arquivos ativos, precisamos debater não apenas quem são esses arquivistas que nos “ordenam" e "organizam", mas principalmente qual é o método empregado para essa sistematização. Será que o depósito em caixas é realmente o melhor processo de organização de nós mesmos enquanto acervo? Não haveria a possibilidade de criarmos caixas e pastas mais flexíveis? Ou sistemas de comunicação que nos permitissem estar simultaneamente em caixas e acervos diferentes? Um método que permitisse a cada objeto a possibilidade de também experimentar o ser de outros objetos? Encurtando as múltiplas possibilidades desse exercício, seria possível - e será que a resposta a esta derradeira pergunta removeria obstáculos mais do que os criaria - pensar nossas sociedades futuras como arquivos inarquiváveis?

\section{Referências}

GORDIMER, Nadine. Onde é que os brancos se encaixam?. In: GORDIMER, Nadine. O gesto essencial: literatura, política e lugares. Trad. Waldéa Barcellos, Rio de Janeiro, Rocco, 1992, p. 41-48.

GORDIMER, Nadine. The lying days, Nova York, Penguin Books, 1994.

GORDIMER, Nadine. Ninguém para me acompanhar, Trad. Beth Vieira, São Paulo, Companhia das Letras, 1996.

GORDIMER, Nadine. Writing and being, Cambridge, Mass./Londres, Harvard University Press, $1996 \mathrm{~b}$.

HEAD, Dominic. Gordimer's None to accompany me: revisionism and interregnum, Research in African Literatures, v. 26, n. 4, p. 46-57, 1995, inv.

PATON, Alan. Cry, the beloved country, Nova York/Londres, Scribner, 2003.

Recebido em 20 de novembro de 2020

Aceito em 15 de dezembro de 2020 